\title{
Mean Reversion in International Equity Markets ${ }^{\star}$
}

\author{
Ömer EREN ${ }^{1} \odot$, Cenk C. KARAHAN ${ }^{2}$
}

\begin{abstract}
Mean reversion is a phenomenon that has been consistently observed and refuted in several studies over the last decades. This study first aims at shedding further light on this unsettled issue by assessing mean reversion on recent data in a broad range of international equity markets including developed and emerging markets and international indices provided by $\mathrm{MSCl}$. Variance ratio computations and a novel distribution-free statistical tests based on randomization are used on dollar denominated nominal, real and excess returns of these equity markets. The results indicate that mean reversion exists in both developed and emerging countries, albeit its statistical significance is occasionally dubitable. Moreover, firm size and return type exhibit significant effects on the degree of mean reversion.
\end{abstract}

Keywords: International Equity Returns; Market Efficiency; Mean Reversion; Variance Ratio

JEL Classification: G1; G14; G15; C14

\section{Introduction}

Movements of stock prices have been a crucial part of the finance literature for decades and probably will continue to be so for decades to come. Practitioners and academics alike have been trying to understand how stock prices move since the early days of modern financial markets in the eighteenth century. There are numerous theories and published papers trying to explain how stock prices change over time. What makes it such a hot topic is that it has the possibility of opening doors to endless economic gains. For example, if we can prove that a certain stock's price has a cyclical behavior (a.k.a. mean reversion) and if we can identify certain properties of that behavior such as the half-life, we can buy that stock when it's at its lowest level and sell it when it's at its highest. There is certainly some degree of randomness in stock prices, therefore we might not be as successful as we'd like in our predictions. Yet it is undeniable that understanding the patterns of stock prices presents us with an incomparable opportunity for profits.

The most dominant theory regarding stock returns is the random walk theory. This theory maintains that holding period returns of a stock are independent from each other. According to this theory, stock prices have no memory; therefore, historical prices have no practical use to us. Advocates of the random walk theory believe it is not possible to outperform the market without bearing any additional risk. Burton Malkiel (1973, p.24), who is credited with popularizing the idea, claims:"a blindfolded monkey throwing darts at a newspaper's financial pages could select a portfolio that would do just as well as one carefully selected by the experts". Assuming he was talking about the risk adjusted returns, what he said would be true if prices were following a random walk.

The popularity of the random walk theory had a dramatic increase with the introduction of the Efficient Markets Hypothesis (hereafter EMH) in the 1960s. In general terms, EMH holds that in an efficient market, "prices fully reflect available information" (Fama, 1970, p.384). Although they are not exactly the same, it is clear that EMH makes a strong case for the random walk theory.

If prices do not follow a random walk and serial correlations between holding-period returns are not

\footnotetext{
* This paper is adapted from Mr. Eren's unpublished Master thesis written during his studies towards MA in Management degree at Boğaziçi University under Dr. Karahan's supervision.

${ }^{1}$ PhD Candidate, Boğaziçi University, Department of Management, Bebek, Istanbul, omer.eren@boun.edu.tr

${ }^{2}$ Assistant Professor, Boğaziçi University, Department of Management, Bebek, Istanbul, cenk.karahan@boun.edu.tr
} 
zero, it means there is a certain degree of predictability in stock prices. Positive serial correlations point towards a trend in stock prices, whether it be increasing or decreasing. This means the stock price in the next period will likely move in the same direction it moved in the last period. This is called momentum and investment strategies based on this idea are called momentum strategies (Jegadeesh and Titman, 1993; Rouwenhorst 1998; Patro and $\mathrm{Wu}, 2004)$. Momentum strategies typically involve buying stocks that performed well in the past and short selling stocks that performed poorly in the past.

In contrast, if serial correlations are negative; stock prices tend to fluctuate around a certain mean or trend. This is called mean reversion (Lo and Mackinlay, 1988; Poterba and Summers, 1989; Richards, 1997; Chaudhuri and Wu, 2003; Gropp, 2004). Investment strategies based on this phenomenon are called contrarian strategies. Contrarian strategies look to buy stocks that have performed poorly in the past and short sell stocks that have performed well in the past. Both of these investment strategies aim to outperform the market by following two diametrically opposite routes.

Coexistence of the two opposing views can be explained by the fact that serial correlations can have different signs for different holding periods or different lags. There might be momentum in the short-term and mean reversion in the long-term or vice versa. In this case, a more sophisticated investment strategy involving both momentum and contrarian perspectives may be adopted (Balvers and Wu, 2006).

If EMH and random walk theory are considered as the traditional paradigm in explaining stock returns, financial market anomalies are the empirical patterns that are in violation of these central ideas. There are numerous empirical anomalies documented over the decades capturing both cross-sectional and time-series patterns in returns of securities. Mean reversion and aversion occupy important places on the list of anomalies violating $\mathrm{EMH}$, even though there are some differences of opinion in the literature.

Fama and French (1988, p.299) argue that serial correlations may be the result of "time varying equilibrium expected returns generated by rational investor behavior". Moreover, Conrad and Kaul (1988) find evidence in favor of a stationary expected return process, which substantiates the earlier statement. Since there is no consensus as to even their existence, we deem it is worthy of further study to explore these phenomena.
Therefore, this study investigates if international equity indices, both developed and emerging, show any signs of these anomalies on recent data using a robust and novel methodology. Even though this subject has been under constant scrutiny for the last three decades, there aren't many studies that look at both developed and emerging markets. Aside from the novelties of our sample set, we also explore the effect of return type and firm size on return predictability. We feel we can make a useful contribution to the literature by comprehensively examining both fronts, through a methodology that does not rely on any assumptions made about the distribution of variance ratios.

Rest of the paper is organized as follows: Section 2 reviews the extant literature on mean reversion and momentum. Section 3 explains the methodology followed throughout the paper and characteristics of the data set. Section 4 discusses the empirical results. Section 5 includes a summarization of the results and some concluding remarks.

\section{Literature Review}

Mean reversion in finance, although observed and discussed for long, came to be rigorously analyzed since 1970's. Vasicek (1977) proposed a mean-reverting Ornstein-Uhlenbeck process to model stochastic interest rates. This extension of continuous time models that have been popularized in the 70's found a natural application in interest rates, as it was long perceived that interest rates exhibit mean reversion in empirical observations. Mean reversion in stock prices, however, was first investigated by DeBondt and Thaler (1985) under the name of price reversals. They formed winner and loser portfolios by ranking all the stocks in the New York Stock Exchange with respect to their past returns. Their findings were remarkable. They found that on average, the loser portfolios earned $24.6 \%$ more than the winner portfolios in the subsequent test period. To show that the difference in returns cannot be explained solely by the difference in risk, they also calculated CAPM betas for winner and loser portfolios for each of the formation period. Surprisingly, not only loser portfolios were outperforming winner portfolios, they were also significantly less risky. They interpreted these findings as the result of overreaction of investors and concluded that this is a violation of weak-form market efficiency. This study paved the way for other researchers to explore this new phenomenon and gain more insight on how stock prices move. 
Chan (1988) challenged DeBondt and Thaler's (1985) results by claiming that their method of measuring the betas of winner and loser portfolios was biased. He suggested an alternative method for measuring risk which involves calculating different betas for the formation and test periods. He repeated the same procedure as DeBondt and Thaler (1985) with the new betas and he found only weak evidence of price reversals. According to his results, abnormal returns to the contrarian strategy were very small, and probably economically insignificant, considering transaction costs and various other factors that can erase that small profit margin.

French and Roll (1986), while investigating the difference in the volatility of stock prices between trading and non-trading hours, reported negative serial correlations in daily returns in all lags up to 13 except lag 1. Although they used these results for a different purpose, these negative auto correlations can still be regarded as significant evidence in favor of short-term mean reversion. The way they calculated these variance ratios is very similar to that of Cochrane (1988), whose methodology was taken as the basis by the likes of Poterba and Summers (1989) and Lo and MacKinlay (1988). Even though they were not concerned with mean reversion at all, they provided substantial evidence for future researchers to move forward with, nonetheless. In fact, this simple idea provided the foundation to test random walk and efficient market hypothesis without being tied to an asset pricing model, a problem which led the academics to question the aforementioned studies.

Lo and MacKinlay (1988) used variance ratios to explore whether or not stock prices follow random walk. They found significant evidence of positive autocorrelations in the weekly data and therefore rejected the random walk hypothesis. They discovered that positive autocorrelations get larger, thus the rejection of random walk stronger, as the firm size decreases.

Fama and French (1988) assumed stock prices consist of two separate AR (1) processes, a permanent component which follows a random walk and a transitory component which is mean reverting. While they did not observe any apparent pattern in industry portfolios, the decile portfolios demonstrated clear patterns that suggest mean-reverting components in prices. The effect of the mean-reverting component diminished however, as the firm size increased.

Poterba and Summers (1989) compared the methods of Fama and French (1988) and Lo and MacKinlay
(1988) with respect to their power in detecting mean reversion and concluded that variance ratio method used by Lo and MacKinlay (1988), although not nearly powerful enough, is much more powerful than the method of Fama and French (1988). Therefore, they used variance ratio tests to investigate if there was long-term mean reversion in stock prices. They test their hypothesis on US as well as a range of international markets. They reported variance ratios separately for nominal, real and excess returns for the value-weighted as well as the equal-weighted indices. Their results suggested positive serial correlation in stock prices in horizons shorter than one year and negative serial correlation in horizons longer than one year. This, together with the results of Lo and MacKinlay (1988), makes a strong case for momentum strategies in the short-term, while advocating for contrarian strategies for the longer horizons.

Kim, Nelson and Startz (1991) criticized the findings of previous studies and went on to perform more robust tests on the issue. In order to test their results, they created empirical distributions of variance ratios and regression coefficients by randomization. To put it simply, they shuffled their data 1000 times and calculated the same statistic for every shuffle to come up with an empirical distribution for their test statistic. The merits of this approach come from the fact that it requires no assumptions about the distribution of the test statistic. This separates them from other researchers who use asymptotic approximations. After testing their results, Kim et al. (1991) concluded that mean reversion was a pre-war phenomenon, hence a statistical fluke of its time. McQueen (1992) also investigated long-term mean reversion in the U.S. market by generalized least squares estimators and could not reject the random walk hypothesis with the GLS method.

Richards (1997) studied winner-loser reversals in international markets and found a momentum effect in horizons shorter than one year and contrarian effect at 3 and 4-year horizons. Balvers, Wu and Gilliland (2000) built a parametric model in which price of a certain index is determined by its deviations from a reference index. With this model, not only they could test the hypothesis of mean reversion, they were also able to find the half-life of mean reversion, if there was any. With a focus on international markets, they could not reject the random walk hypothesis for most of the countries separately. However, when they pooled the data for all 18 countries to gain more statistical power; they were able to reject the random walk hypothesis 
at the 1 percent significance level. Chaudhuri and Wu (2003) also reported strong evidence of mean-reversion in international markets. Gropp (2004) looked for mean reversion in industry stock returns in the USA with a panel approach above and found strong evidence of mean-reversion in contrast with other US-based studies cited above.

Given the earlier evidence supporting both return continuation and mean reversion, Balvers and Wu (2006) developed a trading model that combined momentum and contrarian strategies. They believed that although the mean reversion effect seemed stronger than momentum effect, a single asset could demonstrate both at different holding periods. Their joint strategy outperformed separate momentum and contrarian strategies as well as a pure random walk strategy. Mukherji (2011) revisited the issue of mean reversion with a more recent data. In order to surmount the small sample barrier, he utilized bootstrapping which involved pulling 10-year samples from the original data set 1000 times with replacement. As predicted, he observed a greater tendency for mean reversion in small company stocks. He concluded that although it had weakened in the last decades, mean reversion was still present in the U.S. data; especially for small company stocks.

Spierdijk, Bikker and van den Hoek (2012) tested mean reversion across 18 OECD countries with a data set covering the 1900-2009 period. They were able to reject the null hypothesis of random walk in favor of mean reversion for only 8 countries out of 18 . They conducted a rolling-window test with 27 year-long windows, in which they allowed the speed of mean reversion to be different in each window. According to their results, speed of mean reversion tends to fluctuate a lot over time and it is usually higher in periods of economic instability. This study shows how much the results of such an analysis depend upon the choice of data sample.

Shaik and Maheswaran (2018) presented evidence of mean reversion in the Indian stock market by using expected lifetime range ratios which they claim to be more robust in detecting mean reversion compared to conventional variance ratios.

Jegadeesh $(1990,1991)$ explored the possibility of seasonality in the predictability of stock prices. He found evidence of mean reversion in the U.S. stocks but discovered that the month January was solely responsible for this result. These findings cast a shadow upon the results of Poterba and Summers (1989) and many others and called most of the evidence provided in favor of mean reversion into question.

Although the main focus of this paper is mean reversion, adverting some of the articles on momentum would be helpful in presenting a more comprehensive literature review. Jegadeesh and Titman (1993) tested different momentum-based strategies for the U.S. market over the 1965-1989 period. Their results contributed to the earlier evidence in favor of the general rule of momentum in the short-term/mean reversion in the long-term. Carhart (1997, p.79) claimed "buying last year's top-decile mutual funds and selling last year's bottom-decile mutual funds yields a return of 8 percent per year". Rouwenhorst (1998, p.283) looked at 12 European countries and found that "an internationally diversified portfolio of past winners outperformed a portfolio of past losers by about 1 percent per month". Chan, Hameed and Tong (2000) implemented momentum strategies on international stock markets and found statistically and economically significant returns. Jegadeesh and Titman (2001) asserted that momentum effect continued to persist in U.S. market in the 1990s, more specifically in the eight years subsequent to Jegadeesh and Titman (1993). Lewellen (2002) provided further evidence on momentum by investigating the role of industry, size and book-to-market factors. He showed that even the well-diversified size and book-to-market portfolios exhibited a considerable degree of momentum. Patro and Wu (2004) tried to shed further light on momentum and examined 18 developed markets for the period 1979-1998. They rejected the random walk hypothesis with daily and weekly data for most of the countries. They also noted that these equity indices displayed significant return continuation in the short-term. By analyzing 38 country indices, Bhojraj and Swaminathan (2006) inferred that after the portfolio formation, winners outperformed losers in the first 3 to 12 months, but underperformed losers in the subsequent 2 years.

\section{Data and Methodology}

In order to assess mean reversion, we follow the main methodology of Poterba and Summers (1989) which relies upon variance ratios, with more robust statistical tests based on randomization. There are several reasons behind this selection. There are other ways of detecting mean reversion such as the expected lifetime range ratio method of Shaik and Maheswaran (2018) but that method is relatively new and it hasn't 
stood the test of time. Variance ratio on the other hand, is a model-free test method reliably used over the past decades. Furthermore, it has an easy and intuitive interpretation when coupled with a robust statistical test. Usage of a randomization method to conduct statistical tests frees us from relying on an asset pricing model or a specific distribution, hence yields more unbiased results.

If the return series of a stock follows random walk, the variance of its k-period return must be $k$ times the variance of its 1-period return, assuming we use continuously compounded returns.

$$
R_{k}=r_{1}+r_{2}+\cdots+r_{k}
$$

Here, $R_{k}$ is the k-period return and returns on the right-hand side are 1-period returns. If we want to get the variance of $R_{k}$ :

$$
\operatorname{Var}\left(R_{k}\right)=\sum_{i=1}^{k} \sum_{j=1}^{k} \operatorname{Cov}\left(r_{i}, r_{j}\right)
$$

If the series follows a random walk, returns must be independent from each other. In this case, the equation reduces to:

$$
\operatorname{Var}\left(R_{k}\right)=k \times \sigma^{2}
$$

This proves that under the strict assumptions of random walk, the variance of holding period returns is proportional to the length of the holding period itself. The variance ratio statistic is defined as:

$$
\operatorname{VR}(k)=\frac{\operatorname{Var}\left(r_{t}^{k}\right)}{\operatorname{Var}\left(r_{t}^{1}\right) * k}
$$

where $r_{t}^{\mathrm{k}}$ and $r_{t}^{1}$ are k-period and 1-period returns respectively. From Equation (3), we can see that this statistic has to be in unity for a random walk. Poterba and Summers (1989) used a variation of this statistic in their analysis which is:

$$
\operatorname{VR}(k)=\frac{\operatorname{Var}\left(r_{t}^{k}\right) / k}{\operatorname{Var}\left(r_{t}^{12}\right) / 12}
$$

In other words, they took 12 months as the base period instead of 1 month. This method draws a clear line between short-term (less than 1 year) and longterm (more than 1 year) and makes it easier to make separate inferences about both.

Cochrane (1988) showed that variance ratios can also be expressed as a linear combination of sample autocorrelations:

$$
V R(k) \cong 1+2 \sum_{j=1}^{k-1} \frac{(k-j)}{k} \hat{\rho}(j)
$$

where $\hat{\rho}(j)$ is sample autocorrelation at lag $\mathbf{j}$. From this equation we can see that for $k>1$, positive autocorrelations lead to a variance ratio bigger than 1 and negative autocorrelations lead to a variance ratio smaller than 1 . If autocorrelations at all lags are 0 , which is the case for a perfect random walk, the variance ratio has to be at unity. We can also see that as we go up to higher lags, weights of the autocorrelations decrease, which means lower lag autocorrelations have a larger impact on the variance ratio.

Visual inspection of the variance ratios can give clues to the overall behavior of our time series. If the variance ratios are significantly smaller than 1 , that will lead us to infer that the time-series in question is mean-reverting. On the contrary; if variance ratios are larger than 1 , it is implied that the series is a mean-averting one.

When Poterba and Summers (1989) applied Cochrane's (1988) results to their version of the variance ratio formula, they reached the formulation:

$$
V R(k) \cong 1+2 \sum_{j=1}^{11} j\left(\frac{k-12}{12 k}\right) \hat{\rho}(j)+2 \sum_{j=12}^{k-1} \frac{k-j}{k} \hat{\rho}(j)
$$

The most important practical difference between (6) and (7) is that in the latter; for $k<12$, variance ratios smaller than 1 imply positive autocorrelation and variance ratios larger than 1 imply negative autocorrelation, whereas it is the opposite for (6). However, for $k>12$, it is the same for both formulas. In this version, absolute weights of the autocorrelations increase up to lag 11 and start to decrease after lag 13, forming an inverted V shape.

Kendall and Stuart (1976) showed that under the null hypothesis of serial independence;

$$
E[\hat{\rho}(j)]=-1 /(T-j)
$$

where is the sample autocorrelation at lag $j$ and $T$ is the sample size. This creates a downward bias in variance ratios, pushing them below unity. To avoid this, Poterba and Summers (1989) made a bias correction by calculating the expected value of the variance ratio under the null hypothesis of serial independence and dividing the variance ratios estimated from the sample by this value.

$$
E[V R(k)]=\frac{12+5 k}{6 k}+\frac{2}{k} \sum_{j=1}^{k-1} \frac{T-k}{T-j}-\frac{1}{6} \sum_{j=1}^{11} \frac{T-12}{T-j}
$$


Variance ratios reported in the results section follow this corrected method to compute the variance ratios for holding periods between 1 month to 120 months in overlapping periods over the entire sample period.

Although variance ratios convey very useful information, the null hypothesis of random walk should be statistically tested in order to reach a conclusive result. There are different ways of testing variance ratios. However, most of these methods rely heavily upon several assumptions made about the distribution of stock returns and variance ratios, which may or may not hold in real life. Hence, we use a more robust testing method proposed by Kim et al. (1991) which does not make any assumptions about the underlying distribution.

Kim et al. (1991) utilize a method called randomization which involves creating an empirical distribution of variance ratios by shuffling the data set 1000 times and calculating the variance ratios for each shuffle. By changing the order of returns, shuffling removes any autocorrelation present in the data set, making it as close to random walk as possible. This allows the null hypothesis of random walk or the null hypothesis that the variance ratio equals to 1 , to be tested by comparing the actual variance ratio to the empirical distribution of variance ratios obtained with randomization. If the variance ratio lies below or above a certain percentile (which also serves as the significance level) of the empirical distribution, the null hypothesis can be rejected. If not, it means there is no statistical proof of mean reversion or aversion in the data set.

The data set consists of $16 \mathrm{MSCl}$ (Morgan Stanley Capital International) value-weighted equity indices. Among these 16 indices, 6 of them are developed (USA, UK, France, Germany, Japan and Australia) and 6 of them are emerging (Brazil, Mexico, Turkey, South Africa, China and India) market indices. Obtaining a well-diversified set which includes major developed and emerging markets was the primary aim when choosing the countries. Remaining 4 are World, Emerging Markets, ACWI (All Country World Index) and Frontier Markets indices. World index consists of 23 developed markets and Emerging Markets (hereafter EM) index consists of 24 emerging markets. ACWI index brings together the World and EM indices and covers a total of 47 countries. Lastly, Frontier Markets (hereafter FM) index is composed of 29 frontier markets. Figure 1 shows the list of countries covered by each international index, where each index is tracking the countrywide stock performance by including a subset of stocks in index calculations.
The available data set covers different time periods for different indices. For World, EM and ACWI indices, the data dates back to 1988 . However, the range of the FM index is much shorter and it is only offered since 2002. Developed market indices go back to 1970; Brazil, Mexico and Turkey begin in 1988; South Africa, China and India coverage begins in 1993. The data is obtained from Reuters Datastream up until 2018. All indices are denominated in U.S. dollars rather than local currencies because it is very difficult to find reliable inflation and risk-free interest rate data for all of the listed countries. Furthermore, our unreported preliminary tests on nominal returns denominated in local currencies yielded extreme mean-averting results in some emerging markets, which we attribute to high levels of inflation in those countries.

For the purpose of a detailed analysis; we calculate nominal, real and excess monthly returns on both total return (dividends reinvested) and price indices. The CPI data of U.S. Bureau of Labor Statistics and 1-month Treasury bill rates from WRDS (Wharton Research Data Services) have been used to calculate real and excess returns. Furthermore, small-cap, mid-cap and large-cap World, EM, ACWI indices have also been extracted to investigate any possible size effect. These indices however, begin only in 1994. FM index is not included here because $\mathrm{MSCl}$ does not offer large and mid-cap versions of this index.

Using $\mathrm{MSCl}$ data makes the entire analysis more reliable, standardized and consistent, since the same methodology has been used to calculate all of the indices. This brings all of the countries to even ground and makes them more comparable to each other.

\section{Results}

Upon inspection of the summary statistics of returns reported in Table 1, emerging markets' average return of $0.68 \%$ is significantly higher than the developed markets' average return of $0.46 \%$, which is to be expected since their volatility is also considerably higher with $6.68 \%$ standard deviation compared to the $4.25 \%$ of developed markets. We can see that the ACWI index is dominated by developed markets as its average return and standard deviation is almost identical to those of the World index. Surprisingly, frontier markets sit between developed and emerging markets in terms of both metrics. In fact, the average return and standard deviation of frontier markets are very close to their developed counterparts. 


\begin{tabular}{|c|c|c|c|c|c|}
\hline \multicolumn{6}{|c|}{ MSCI ACWI INDEX } \\
\hline \multicolumn{3}{|c|}{ MSCI WORLD INDEX } & \multicolumn{3}{|c|}{ MSCI EMERGING MARKETS INDEX } \\
\hline \multicolumn{3}{|c|}{ DEVELOPED MARKETS } & \multicolumn{3}{|c|}{ EMERGING MARKETS } \\
\hline Americas & $\begin{array}{c}\text { Europe \& } \\
\text { Middle East }\end{array}$ & Pacific & Americas & $\begin{array}{c}\text { Europe, Middle } \\
\text { East \& Africa }\end{array}$ & Asia \\
\hline $\begin{array}{l}\text { Canada } \\
\text { United States }\end{array}$ & $\begin{array}{l}\text { Austria } \\
\text { Belgium } \\
\text { Denmark } \\
\text { Finland } \\
\text { France } \\
\text { Germany } \\
\text { Ireland } \\
\text { Israel } \\
\text { Italy } \\
\text { Netherlands } \\
\text { Norway } \\
\text { Portugal } \\
\text { Spain } \\
\text { Sweden } \\
\text { Switzerland } \\
\text { United } \\
\text { Kingdom }\end{array}$ & $\begin{array}{l}\text { Australia } \\
\text { Hong Kong } \\
\text { Japan } \\
\text { New Zealand } \\
\text { Singapore }\end{array}$ & $\begin{array}{l}\text { Brazil } \\
\text { Chile } \\
\text { Colombia } \\
\text { Mexico } \\
\text { Peru }\end{array}$ & $\begin{array}{l}\text { Czech } \\
\text { Republic } \\
\text { Egypt } \\
\text { Greece } \\
\text { Hungary } \\
\text { Poland } \\
\text { Qatar } \\
\text { Russia } \\
\text { South Africa } \\
\text { Turkey } \\
\text { United Arab } \\
\text { Emirates }\end{array}$ & $\begin{array}{l}\text { China } \\
\text { India } \\
\text { Indonesia } \\
\text { Korea } \\
\text { Malaysia } \\
\text { Pakistan } \\
\text { Philippines } \\
\text { Taiwan } \\
\text { Thailand }\end{array}$ \\
\hline
\end{tabular}

MSCI FRONTIER MARKETS INDEX

\begin{tabular}{|c|c|c|}
\hline \multicolumn{3}{|c|}{ FRONTIER MARKETS } \\
\hline Americas & $\begin{array}{c}\text { Europe, Middle } \\
\text { East \& Africa }\end{array}$ & Asia \\
\hline Argentina & $\begin{array}{l}\text { Bahrain } \\
\text { Burkina Faso } \\
\text { Benin } \\
\text { Croatia } \\
\text { Estonia } \\
\text { Guinea-Bissau } \\
\text { Ivory Coast } \\
\text { Jordan } \\
\text { Kenya } \\
\text { Kuwait } \\
\text { Lebanon } \\
\text { Lithuania } \\
\text { Mauritius } \\
\text { Mali } \\
\text { Morocco } \\
\text { Niger } \\
\text { Nigeria } \\
\text { Oman } \\
\text { Romania } \\
\text { Senegal } \\
\text { Serbia } \\
\text { Slovenia } \\
\text { Togo } \\
\text { Tunisia }\end{array}$ & $\begin{array}{l}\text { Bangladesh } \\
\text { Kazakhstan } \\
\text { Sri Lanka } \\
\text { Vietnam }\end{array}$ \\
\hline
\end{tabular}

Figure 1: Breakdown of the MSCI Indices. 
We can see the differences between developed and emerging markets in more detail in the second panel of Table 1. None of the emerging markets has a lower volatility than any of the developed markets, as expected. However, this trend does not fully extend to average returns. Some of the emerging markets have lower average returns than developed markets, such as Turkey with $0.4 \%$ average return and China with $-0.04 \%$ average return. China's results are particularly interesting since it does not provide a positive return for a substantial amount of risk. Moreover, Australia has the lowest average monthly return among all the developed markets with $0.37 \%$, despite being the most volatile with $7.11 \%$ standard deviation.

On the other hand, these results are obtained with returns that are denominated in USD rather than local currencies and standard deviation is not the only measure of risk, nor the most accurate one. Therefore, Table 1 only gives us a rough idea about the characteristics of our data set and serves as a starting point for our analysis.

\subsection{International Results}

As a starting point of our analyses, we report below the variance ratios for broad international indices, namely World, EM, ACWI and FM indices for nominal, real and excess monthly log-returns, respectively. There aren't any drastic differences between the three plots and all four indices exhibit some degree of mean reversion in all of them. World and ACWI indices seem to be going hand in hand, which further proves that companies in the former dominate the ACWI index.

Interestingly, World index shows stronger mean reversion than the $\mathrm{EM}$ index in all return types for holding periods longer than 5 years. However, for holding periods shorter than 5 years, EM index is below the others in terms of variance ratios, by a big margin. FM index stays close to World and ACWI indices until around 80 months and then jumps ahead and starts to approach unity which is the hallmark of random walk. Moreover, there are signs of mean aversion, or momentum, in holding periods up to 1 year in all four indices, with FM index being the strongest. In this broad overlook, there doesn't seem to be any significant difference in variance ratio patterns between different return types and further investigation is needed to gain more insight into this matter.

Table 1: Summary Statistics of Monthly Index Returns.

\begin{tabular}{lcc}
\hline Index & Average Return (per month) & Standard Deviation of Returns (per month) \\
\hline World & $0.46 \%$ & $4.25 \%$ \\
EM & $0.68 \%$ & $6.68 \%$ \\
ACWI & $0.45 \%$ & $4.33 \%$ \\
Frontier & $0.48 \%$ & $5.32 \%$ \\
\hline USA & $0.56 \%$ & $4.37 \%$ \\
UK & $0.44 \%$ & $6.05 \%$ \\
France & $0.51 \%$ & $6.43 \%$ \\
Germany & $0.55 \%$ & $6.31 \%$ \\
Japan & $0.61 \%$ & $5.93 \%$ \\
Australia & $0.37 \%$ & $7.11 \%$ \\
Brazil & $0.84 \%$ & $14.43 \%$ \\
Mexico & $1.10 \%$ & $8.66 \%$ \\
Turkey & $0.40 \%$ & $14.95 \%$ \\
South Africa & $0.60 \%$ & $7.74 \%$ \\
China & $-0.04 \%$ & $9.51 \%$ \\
India & $0.60 \%$ & $8.34 \%$ \\
\hline
\end{tabular}

This table reports summary statistics of the monthly nominal log-returns of all MSCl equity indices considered in this study. 


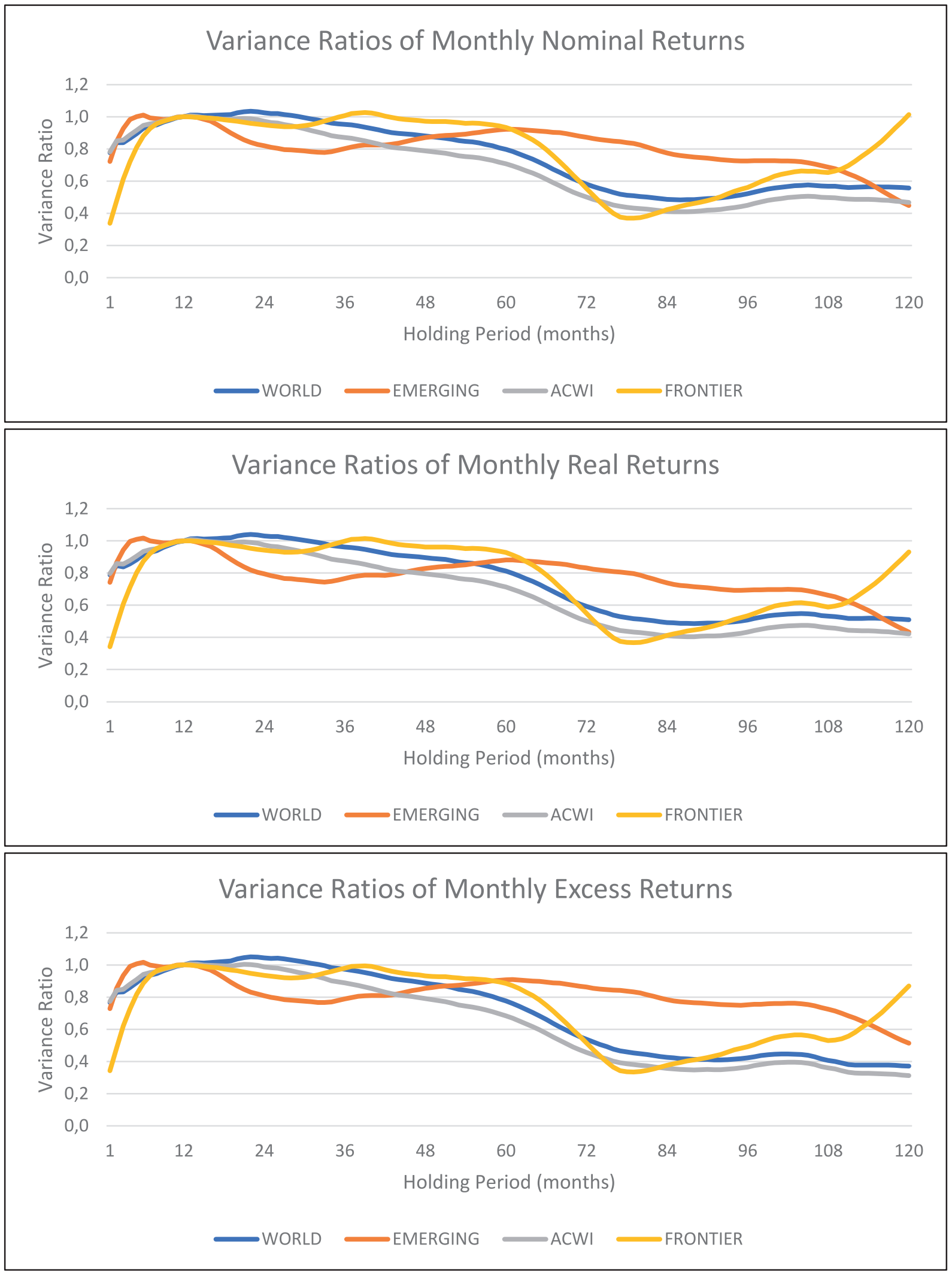

These figures display the variance ratios of monthly nominal, real and excess log-returns, respectively, for MSCI World, EM, ACWI and FM indices from 1 month to 120 months holding periods.

Figure 2: Variance Ratios for International Indices Across Different Holding Periods. 
Table 2 reports the actual variance ratios for several holding periods, as well as the p-values obtained against the distribution of randomized ordering of returns for all return types and all four indices. Since the p-values are obtained from an empirical distribution via randomization, it is free from the shortcomings of assuming a standard distribution like normal.

According to Table 2, although there was an obvious and consistent trend of mean reversion in Figure 2; we cannot statistically reject the null hypothesis of random walk with conventional significance levels for holding periods larger than 1 year. This is true for all indices and for all return types. However, we can reject the null hypothesis of random walk for EM and FM indices for the 1-month holding period with a significance level of $10 \%$ on all return types. Same is true for World and ACWI indices too, except for the real returns. Sheer size of the $p$-values show that mean aversion is the strongest in frontier markets and weakest in developed markets.

In summary, we observe statistically significant results signaling strong momentum effect in emerging and frontier markets and moderate momentum effect in developed markets in very short holding periods. But we cannot find any substantial statistical evidence of mean reversion for any holding period in any of the indices.

Table 2: Variance Ratios and Statistical Tests of Significance for the International Indices.

\begin{tabular}{|c|c|c|c|c|c|c|c|c|c|}
\hline & & $\begin{array}{c}1 \\
\text { month }\end{array}$ & $\begin{array}{c}6 \\
\text { months }\end{array}$ & $\begin{array}{c}24 \\
\text { months }\end{array}$ & $\begin{array}{c}36 \\
\text { months }\end{array}$ & $\begin{array}{c}48 \\
\text { months }\end{array}$ & $\begin{array}{c}72 \\
\text { months }\end{array}$ & $\begin{array}{c}96 \\
\text { months }\end{array}$ & $\begin{array}{c}120 \\
\text { months }\end{array}$ \\
\hline \multicolumn{10}{|c|}{ PANEL A: NOMINAL RETURNS } \\
\hline \multirow[t]{2}{*}{ WORLD } & Variance Ratio & 0.777 & 0.928 & 1.024 & 0.953 & 0.881 & 0.582 & 0.522 & 0.558 \\
\hline & P-value & 0.088 & 0.223 & 0.572 & 0.466 & 0.415 & 0.213 & 0.250 & 0.367 \\
\hline \multirow[t]{2}{*}{ EM } & Variance Ratio & 0.722 & 1.010 & 0.819 & 0.803 & 0.870 & 0.873 & 0.726 & 0.449 \\
\hline & P-value & 0.038 & 0.487 & 0.168 & 0.278 & 0.437 & 0.529 & 0.464 & 0.265 \\
\hline \multirow[t]{2}{*}{ ACWI } & Variance Ratio & 0.782 & 0.946 & 0.971 & 0.871 & 0.788 & 0.502 & 0.451 & 0.469 \\
\hline & P-value & 0.090 & 0.289 & 0.455 & 0.354 & 0.325 & 0.144 & 0.168 & 0.266 \\
\hline \multirow[t]{2}{*}{ FM } & Variance Ratio & 0.338 & 0.880 & 0.949 & 1.008 & 0.973 & 0.555 & 0.562 & 1.013 \\
\hline & P-value & 0.000 & 0.173 & 0.489 & 0.588 & 0.605 & 0.355 & 0.456 & 0.673 \\
\hline \multicolumn{10}{|c|}{ PANEL B: REAL RETURNS } \\
\hline \multirow[t]{2}{*}{ WORLD } & Variance Ratio & 0.789 & 0.916 & 1.030 & 0.962 & 0.895 & 0.593 & 0.509 & 0.510 \\
\hline & P-value & 0.129 & 0.232 & 0.602 & 0.546 & 0.520 & 0.330 & 0.345 & 0.421 \\
\hline \multirow[t]{2}{*}{ EM } & Variance Ratio & 0.742 & 1.018 & 0.794 & 0.767 & 0.829 & 0.831 & 0.694 & 0.434 \\
\hline & P-value & 0.060 & 0.528 & 0.113 & 0.204 & 0.373 & 0.481 & 0.426 & 0.248 \\
\hline \multirow[t]{2}{*}{ ACWI } & Variance Ratio & 0.796 & 0.935 & 0.974 & 0.874 & 0.794 & 0.503 & 0.433 & 0.422 \\
\hline & P-value & 0.114 & 0.243 & 0.479 & 0.358 & 0.328 & 0.162 & 0.188 & 0.239 \\
\hline \multirow[t]{2}{*}{ FM } & Variance Ratio & 0.343 & 0.873 & 0.942 & 0.998 & 0.962 & 0.550 & 0.533 & 0.931 \\
\hline & P-value & 0.000 & 0.084 & 0.388 & 0.539 & 0.525 & 0.182 & 0.254 & 0.637 \\
\hline \multicolumn{10}{|c|}{ PANEL C: EXCESS RETURNS } \\
\hline \multirow[t]{2}{*}{ WORLD } & Variance Ratio & 0.767 & 0.923 & 1.043 & 0.972 & 0.887 & 0.538 & 0.422 & 0.371 \\
\hline & P-value & 0.076 & 0.198 & 0.633 & 0.513 & 0.447 & 0.173 & 0.143 & 0.141 \\
\hline \multirow[t]{2}{*}{ EM } & Variance Ratio & 0.728 & 1.016 & 0.808 & 0.789 & 0.855 & 0.862 & 0.752 & 0.514 \\
\hline & P-value & 0.038 & 0.540 & 0.128 & 0.230 & 0.402 & 0.496 & 0.455 & 0.317 \\
\hline \multirow[t]{2}{*}{ ACWI } & Variance Ratio & 0.773 & 0.941 & 0.988 & 0.888 & 0.791 & 0.457 & 0.366 & 0.312 \\
\hline & P-value & 0.075 & 0.269 & 0.487 & 0.367 & 0.323 & 0.107 & 0.100 & 0.105 \\
\hline \multirow[t]{2}{*}{ FM } & Variance Ratio & 0.343 & 0.887 & 0.935 & 0.980 & 0.932 & 0.515 & 0.491 & 0.870 \\
\hline & P-value & 0.000 & 0.163 & 0.487 & 0.635 & 0.621 & 0.362 & 0.367 & 0.567 \\
\hline
\end{tabular}

This table reports variance ratios and their respective $\mathrm{p}$-values obtained through randomization of monthly nominal, real and excess log-returns of MSCI World, EM, ACWI and FM indices for several holding periods. 
In order to see if the results are swayed by dividend payments in equity markets, we conduct tests with index values that include only capital gains against those with total returns including dividend payments. This comparison is made for all four indices and with nominal, real and excess monthly log-returns. In unreported results, we observe that the results are almost identical for price and total return indices and the impact of dividend adjustments was negligible. Hence, it can be argued that dividend payments do not constitute a significant difference for the purpose of variance ratio analysis.

In order to test the impact of size on mean reversion, we conduct tests with size-based indices. Figure 3 and Table 3 compare the variance ratios of large-cap, midcap, and small-cap versions of World, EM, and ACWI indices. FM index has been excluded from this part of the analysis because it only had the small-cap index. Again, this analysis is carried out for nominal, real and excess monthly log-returns separately. Since the results are very similar, only the results of nominal returns are reported here for brevity.

Figure 3 shows that World and ACWI indices are still very similar in terms of size-based comparison. Between 12 and 60 months, small-cap index shows the strongest mean reversion, followed by mid-cap and large-cap indices respectively. Small and mid-cap indices are very close to each other, especially for ACWI, whereas the large-cap index is further separated from the other two, even going beyond unity at certain holding periods.
However, second halves of these plots are much more complex and harder to interpret.

EM indices seem to be mean reverting until around 30 months, after which variance ratios start to increase. In terms of the degree of mean reversion, large-cap index is in the lead while the other two are closer to unity, or random walk. Variance ratios start to decrease again after 8 years, which is a very long holding period.

In holding periods shorter than 1 year, all the indices exhibit mean aversion, or momentum; but the sorting is different compared to long-term. For World and ACWI; large-cap index has the strongest momentum, followed by mid-cap and small-cap indices; which means size has an opposite effect here. In the long-term, as the firm size gets bigger; return series approaches random walk whereas in the short-term larger size leads to stronger momentum. On the other hand, large-cap index of the emerging markets shows the weakest momentum in the short-term compared to mid and small-cap indices which have almost identical variance ratios.

In summary, in the long-term, smaller size seems to be resulting in stronger mean reversion for developed markets and somewhat weaker mean reversion for emerging markets. On the contrary, in the short-term, smaller size leads to weaker momentum for developed markets and stronger momentum for emerging markets.

Table 3 reports the results confirming these results with numerical $p$-values, although they do not allow for rejection of the random walk hypothesis except for very short holding periods. 

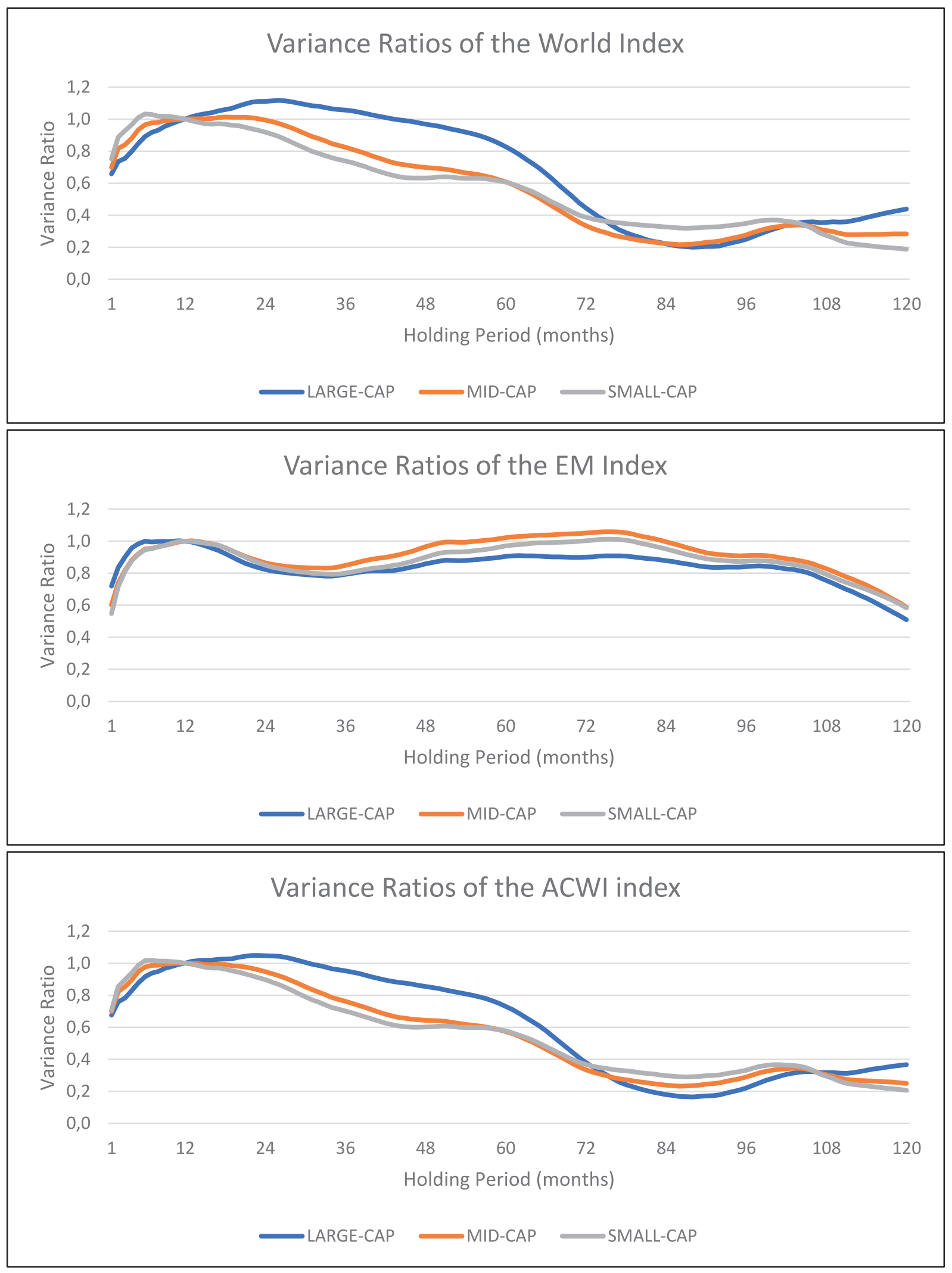

These figures display the variance ratios of monthly nominal returns for MSCI World, EM and ACWI large-cap, mid-cap and small-cap indices, respectively, from 1 month to 120 months holding periods. Since the results for excess and real returns are qualitatively similar, they are not reported here for brevity.

Figure 3: Variance Ratios for Size-Based International Indices Across Different Holding Periods. 
Table 3: Variance Ratios and Statistical Tests of Significance for the Size-Based International Indices.

\begin{tabular}{|c|c|c|c|c|c|c|c|c|c|}
\hline & & $\begin{array}{c}1 \\
\text { month }\end{array}$ & $\begin{array}{c}6 \\
\text { months }\end{array}$ & $\begin{array}{c}24 \\
\text { months }\end{array}$ & $\begin{array}{c}36 \\
\text { months }\end{array}$ & $\begin{array}{c}48 \\
\text { months }\end{array}$ & $\begin{array}{c}72 \\
\text { months }\end{array}$ & $\begin{array}{c}96 \\
\text { months }\end{array}$ & $\begin{array}{c}120 \\
\text { months }\end{array}$ \\
\hline \multicolumn{10}{|c|}{ PANEL A: LARGE-CAP } \\
\hline \multirow[t]{2}{*}{ WORLD } & Variance Ratio & 0.658 & 0.892 & 1.112 & 1.057 & 0.969 & 0.446 & 0.251 & 0.439 \\
\hline & P-value & 0.014 & 0.134 & 0.779 & 0.645 & 0.561 & 0.150 & 0.054 & 0.317 \\
\hline \multirow[t]{2}{*}{ EM } & Variance Ratio & 0.720 & 1.000 & 0.823 & 0.794 & 0.858 & 0.901 & 0.841 & 0.510 \\
\hline & P-value & 0.067 & 0.488 & 0.199 & 0.302 & 0.447 & 0.548 & 0.556 & 0.377 \\
\hline \multirow[t]{2}{*}{ ACWI } & Variance Ratio & 0.676 & 0.916 & 1.046 & 0.953 & 0.854 & 0.380 & 0.221 & 0.366 \\
\hline & P-value & 0.031 & 0.199 & 0.648 & 0.514 & 0.458 & 0.101 & 0.033 & 0.219 \\
\hline \multicolumn{10}{|c|}{ PANEL B: MID-CAP } \\
\hline \multirow[t]{2}{*}{ WORLD } & Variance Ratio & 0.698 & 0.965 & 0.994 & 0.824 & 0.699 & 0.336 & 0.278 & 0.283 \\
\hline & P-value & 0.044 & 0.350 & 0.545 & 0.324 & 0.259 & 0.063 & 0.061 & 0.118 \\
\hline \multirow[t]{2}{*}{ EM } & Variance Ratio & 0.602 & 0.952 & 0.866 & 0.849 & 0.965 & 1.051 & 0.910 & 0.589 \\
\hline & P-value & 0.008 & 0.358 & 0.260 & 0.368 & 0.554 & 0.653 & 0.623 & 0.457 \\
\hline \multirow[t]{2}{*}{$\mathrm{ACWI}$} & Variance Ratio & 0.698 & 0.977 & 0.948 & 0.761 & 0.644 & 0.335 & 0.290 & 0.250 \\
\hline & P-value & 0.049 & 0.395 & 0.435 & 0.243 & 0.204 & 0.055 & 0.058 & 0.065 \\
\hline \multicolumn{10}{|c|}{ PANEL C: SMALL-CAP } \\
\hline \multirow[t]{2}{*}{ WORLD } & Variance Ratio & 0.753 & 1.033 & 0.920 & 0.739 & 0.633 & 0.388 & 0.349 & 0.189 \\
\hline & P-value & 0.083 & 0.601 & 0.367 & 0.213 & 0.188 & 0.083 & 0.125 & 0.028 \\
\hline \multirow[t]{2}{*}{ EM } & Variance Ratio & 0.549 & 0.947 & 0.850 & 0.802 & 0.901 & 1.003 & 0.875 & 0.584 \\
\hline & P-value & 0.002 & 0.289 & 0.237 & 0.326 & 0.493 & 0.645 & 0.613 & 0.463 \\
\hline \multirow[t]{2}{*}{$\mathrm{ACWI}$} & Variance Ratio & 0.706 & 1.015 & 0.897 & 0.701 & 0.601 & 0.368 & 0.332 & 0.206 \\
\hline & P-value & 0.043 & 0.504 & 0.338 & 0.195 & 0.176 & 0.090 & 0.124 & 0.038 \\
\hline
\end{tabular}

This table reports variance ratios and their respective p-values obtained through randomization of monthly nominal log-returns of large-cap, mid-cap and small-cap versions of MSCI World, EM and ACWI indices for several holding periods. Since the results for excess and real returns are qualitatively similar, they are not reported here for brevity.

\subsection{Country Based Results}

Since, the international indices did not yield conclusive statistical results on the existence of mean reversion, we carried on testing the individual countries to assess if less diversified single country equity indices display any significant violation of random walk. Figure 4 plots the variance ratios of the monthly nominal log-returns of all 12 national indices. The results suggest that there is a wide spread of behavior patterns across countries, confirming the need to delve into individual countries to explore the results further.

Among the developed markets, Japan stands out as the only country which shows mean-averting behavior, especially for holding periods more than 6 years. Its variance ratios even go beyond 1.6 at the higher end. USA's variance ratios fluctuate around unity, which is an indication that it follows more or less a random walk. The rest; namely UK, France, Germany and Australia display various degrees of mean reversion. Australia seems to be the strongest in this regard, followed by Germany. Variance ratios of UK and France are very close and they show weaker tendencies for mean reversion compared to Australia and Germany.

Emerging markets are more dispersed compared to developed markets, with a wider range of variance ratios and more complicated trends. Turkey is undoubtedly the most mean-reverting country here, with a sizable difference in variance ratios between her and others. Its variance ratios go even below 0.2 at certain holding periods. Although not as dramatic as Turkey, India also exhibits mean-reverting behavior, especially between 12 and 48 months.

Brazil displays varying behavior throughout the range of holding periods. Its variance ratios are on a downward slope between 12 and 24 months, which is a sign of mean reversion, but they start to increase after that point, reaching almost unity at 60 months. Then they start to decrease again and continue to do so until the end of the range. South Africa seems to follow a random walk in holding periods between 12 and 60 months but its variance ratios start to decline after that point, pushing it towards the mean reversion zone. 

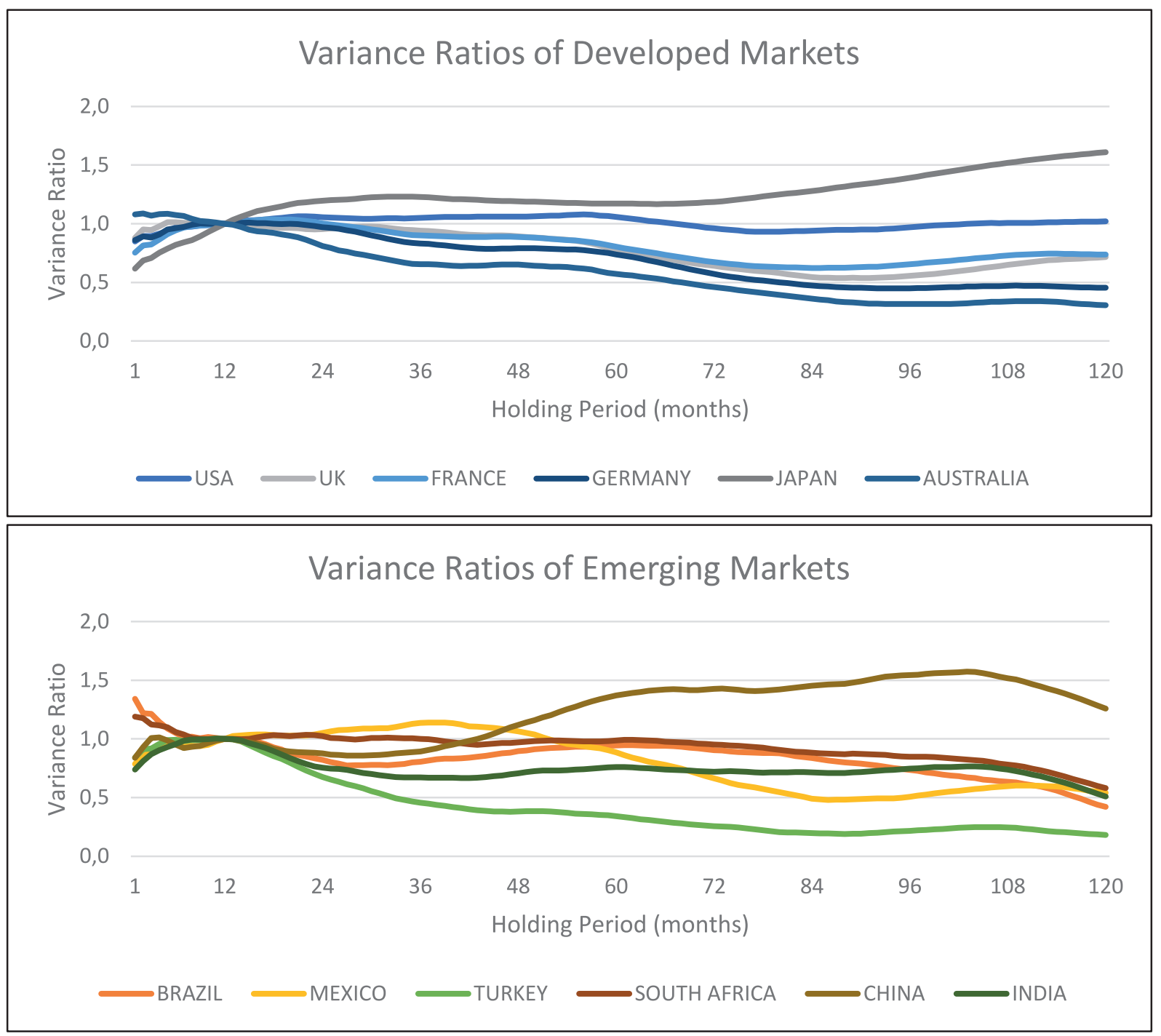

These figures display the variance ratios of the monthly nominal log-returns of $6 \mathrm{MSCl}$ developed market indices (USA, UK, France, Germany, Japan and Australia) and $6 \mathrm{MSCl}$ emerging market indices (Brazil, Mexico, Turkey, South Africa, China and India) for holding periods from 1 month to 120 months.

Figure 4: Variance Ratios for Nominal Returns of Country Indices.

Mexico and China have the most interesting results among the emerging markets. Mexico seems to be mean-averting between 12 and 48 months and mean-reverting for longer holding periods, forming an $\mathrm{S}$ shape. China on the other hand, starts out as a mean-reverting country after 12 months but surpasses unity at around 40 months and becomes a mean-averting country. A quite strong one as well, with variance ratios reaching almost 1.6. In the short-term, Brazil show a quite strong tendency for mean reversion and South Africa follows it with a slightly weaker one, while the rest seem to exhibit mean-averting behavior.

Table 4 displays the actual variance ratios and their p-values of the time series in Figure 4 for certain holding periods. When the statistical evidence is taken into consideration, there is almost no significant statistical proof to most of the inferences made from Figure 4. However, there are some exceptions to this: Turkey and Australia have substantial proof of mean reversion in several holding periods. Turkey's p-values are especially small, proving its mean-reverting behavior beyond any reasonable doubt. Japan's mean aversion also has some merit, since the null hypothesis of random walk can be rejected in holding periods up to 24 months.

Aside from that, there is also proof that France violates random walk in very short holding periods but that is as far as it goes with a significance level of $5 \%$. If a significance level of $10 \%$ is used, this list can be extended to a few more countries and holding periods. 
Table 4: Variance Ratios and Statistical Tests of Significance for Nominal Returns of Country Indices.

\begin{tabular}{|c|c|c|c|c|c|c|c|c|c|}
\hline & & $\begin{array}{c}1 \\
\text { month }\end{array}$ & $\begin{array}{c}6 \\
\text { months }\end{array}$ & $\begin{array}{c}24 \\
\text { months }\end{array}$ & $\begin{array}{c}36 \\
\text { months }\end{array}$ & $\begin{array}{c}48 \\
\text { months }\end{array}$ & $\begin{array}{c}72 \\
\text { months }\end{array}$ & $\begin{array}{c}96 \\
\text { months }\end{array}$ & $\begin{array}{c}120 \\
\text { months }\end{array}$ \\
\hline \multicolumn{10}{|c|}{ PANEL A: DEVELOPED MARKETS } \\
\hline \multirow[t]{2}{*}{ USA } & Variance Ratio & 0.850 & 0.969 & 1.055 & 1.051 & 1.060 & 0.961 & 0.968 & 1.019 \\
\hline & P-value & 0.123 & 0.340 & 0.708 & 0.666 & 0.657 & 0.541 & 0.561 & 0.614 \\
\hline \multirow[t]{2}{*}{ UK } & Variance Ratio & 0.878 & 1.013 & 0.954 & 0.941 & 0.892 & 0.640 & 0.555 & 0.715 \\
\hline & P-value & 0.177 & 0.523 & 0.402 & 0.447 & 0.409 & 0.185 & 0.170 & 0.390 \\
\hline \multirow[t]{2}{*}{ FRANCE } & Variance Ratio & 0.754 & 0.942 & 1.002 & 0.901 & 0.887 & 0.674 & 0.655 & 0.738 \\
\hline & P-value & 0.029 & 0.217 & 0.534 & 0.344 & 0.383 & 0.193 & 0.250 & 0.385 \\
\hline \multirow[t]{2}{*}{ GERMANY } & Variance Ratio & 0.860 & 0.962 & 0.970 & 0.831 & 0.790 & 0.572 & 0.449 & 0.454 \\
\hline & P-value & 0.154 & 0.310 & 0.437 & 0.220 & 0.249 & 0.104 & 0.076 & 0.132 \\
\hline \multirow[t]{2}{*}{ JAPAN } & Variance Ratio & 0.618 & 0.820 & 1.196 & 1.228 & 1.192 & 1.186 & 1.391 & 1.610 \\
\hline & P-value & 0.001 & 0.002 & 0.955 & 0.891 & 0.799 & 0.749 & 0.839 & 0.897 \\
\hline \multirow[t]{2}{*}{ AUSTRALIA } & Variance Ratio & 1.079 & 1.073 & 0.810 & 0.654 & 0.651 & 0.460 & 0.316 & 0.305 \\
\hline & P-value & 0.662 & 0.779 & 0.065 & 0.031 & 0.088 & 0.049 & 0.019 & 0.034 \\
\hline \multicolumn{10}{|c|}{ PANEL B: EMERGING MARKETS } \\
\hline \multirow[t]{2}{*}{ BRAZIL } & Variance Ratio & 1.340 & 1.051 & 0.822 & 0.806 & 0.895 & 0.904 & 0.737 & 0.420 \\
\hline & P-value & 0.912 & 0.680 & 0.150 & 0.256 & 0.453 & 0.549 & 0.465 & 0.217 \\
\hline \multirow[t]{2}{*}{ MEXICO } & Variance Ratio & 0.785 & 0.971 & 1.049 & 1.136 & 1.063 & 0.664 & 0.507 & 0.542 \\
\hline & P-value & 0.092 & 0.384 & 0.630 & 0.713 & 0.614 & 0.290 & 0.232 & 0.348 \\
\hline \multirow[t]{2}{*}{ TURKEY } & Variance Ratio & 0.840 & 0.992 & 0.675 & 0.456 & 0.381 & 0.256 & 0.216 & 0.182 \\
\hline & P-value & 0.155 & 0.445 & 0.021 & 0.007 & 0.009 & 0.007 & 0.007 & 0.007 \\
\hline SOUTH & Variance Ratio & 1.188 & 1.059 & 1.025 & 1.001 & 0.969 & 0.952 & 0.848 & 0.581 \\
\hline AFRICA & P-value & 0.737 & 0.657 & 0.593 & 0.558 & 0.551 & 0.607 & 0.586 & 0.415 \\
\hline \multirow[t]{2}{*}{ CHINA } & Variance Ratio & 0.840 & 0.951 & 0.876 & 0.893 & 1.120 & 1.425 & 1.543 & 1.257 \\
\hline & P-value & 0.184 & 0.321 & 0.284 & 0.423 & 0.698 & 0.842 & 0.873 & 0.815 \\
\hline \multirow[t]{2}{*}{ INDIA } & Variance Ratio & 0.739 & 0.954 & 0.753 & 0.671 & 0.707 & 0.720 & 0.745 & 0.510 \\
\hline & P-value & 0.069 & 0.338 & 0.103 & 0.143 & 0.277 & 0.411 & 0.516 & 0.383 \\
\hline
\end{tabular}

This table reports variance ratios and their respective $p$-values obtained through randomization of monthly nominal logreturns of $12 \mathrm{MSCl}$ equity indices for several holding periods. Panel A reports the results for developed market indices and Panel $\mathrm{B}$ reports the results for emerging market indices.

Figure 5 and Table 5 show the results of the same analysis done with real returns. They are qualitatively similar to the results for nominal returns. USA constitutes the biggest difference between the two. It has gone from being the most prominent random walk among all 12 markets to having the highest variance ratios among developed markets. However, it is still a random walk from a purely statistical perspective since none of its p-values are below 0.05 .
Moreover, Australia's mean reversion is toned down in real returns as its variance ratios and $p$-values are higher. In result, null hypothesis of random walk can be rejected for fewer holding periods. In addition to that, Japan's mean aversion is also weaker compared to nominal returns but we couldn't reject the null hypothesis to begin with, so it is not a major concern. The impact of inflation is visible in certain countries, yet not to the extent to change the statistical significance of the results. 


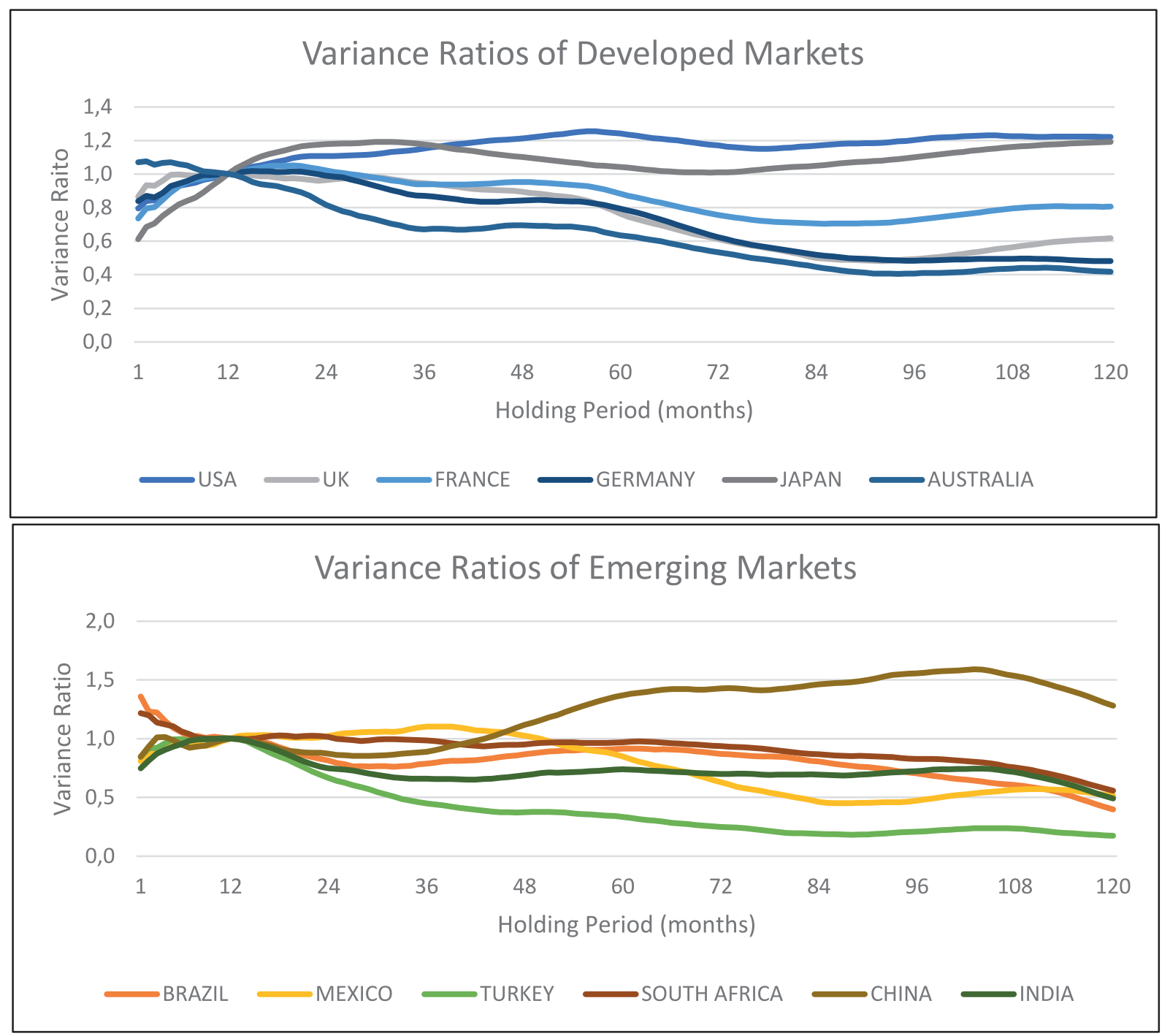

These figures display the variance ratios of the monthly real log-returns, as computed by the difference between the monthly nominal return and monthly US inflation, of $6 \mathrm{MSCl}$ developed market indices (USA, UK, France, Germany, Japan and Australia) and 6 MSCl emerging market indices (Brazil, Mexico, Turkey, South Africa, China and India) for holding periods from 1 month to 120 months.

Figure 5: Variance Ratios for Real Returns of Country Indices. 
Table 5: Variance Ratios and Statistical Tests of Significance for Real Returns of Country Indices.

\begin{tabular}{|c|c|c|c|c|c|c|c|c|c|}
\hline & & $\begin{array}{c}1 \\
\text { month }\end{array}$ & $\begin{array}{c}6 \\
\text { months }\end{array}$ & $\begin{array}{c}24 \\
\text { months }\end{array}$ & $\begin{array}{c}36 \\
\text { months }\end{array}$ & $\begin{array}{c}48 \\
\text { months }\end{array}$ & $\begin{array}{c}72 \\
\text { months }\end{array}$ & $\begin{array}{c}96 \\
\text { months }\end{array}$ & $\begin{array}{c}120 \\
\text { months }\end{array}$ \\
\hline \multicolumn{10}{|c|}{ PANEL A: DEVELOPED MARKETS } \\
\hline \multirow[t]{2}{*}{ USA } & Variance Ratio & 0.795 & 0.929 & 1.107 & 1.152 & 1.212 & 1.170 & 1.202 & 1.221 \\
\hline & P-value & 0.063 & 0.190 & 0.804 & 0.778 & 0.797 & 0.706 & 0.722 & 0.742 \\
\hline \multirow[t]{2}{*}{ UK } & Variance Ratio & 0.865 & 0.997 & 0.963 & 0.945 & 0.894 & 0.613 & 0.493 & 0.618 \\
\hline & P-value & 0.158 & 0.451 & 0.407 & 0.450 & 0.401 & 0.142 & 0.105 & 0.267 \\
\hline \multirow[t]{2}{*}{ FRANCE } & Variance Ratio & 0.735 & 0.926 & 1.021 & 0.939 & 0.952 & 0.757 & 0.726 & 0.806 \\
\hline & P-value & 0.017 & 0.152 & 0.578 & 0.416 & 0.483 & 0.284 & 0.325 & 0.442 \\
\hline \multirow[t]{2}{*}{ GERMANY } & Variance Ratio & 0.839 & 0.943 & 0.991 & 0.869 & 0.843 & 0.625 & 0.483 & 0.481 \\
\hline & P-value & 0.118 & 0.233 & 0.510 & 0.289 & 0.326 & 0.173 & 0.108 & 0.163 \\
\hline \multirow[t]{2}{*}{ JAPAN } & Variance Ratio & 0.613 & 0.819 & 1.178 & 1.176 & 1.102 & 1.010 & 1.099 & 1.191 \\
\hline & P-value & 0.000 & 0.003 & 0.933 & 0.814 & 0.692 & 0.587 & 0.676 & 0.727 \\
\hline \multirow[t]{2}{*}{ AUSTRALIA } & Variance Ratio & 1.070 & 1.059 & 0.815 & 0.671 & 0.695 & 0.533 & 0.408 & 0.419 \\
\hline & P-value & 0.661 & 0.738 & 0.076 & 0.049 & 0.130 & 0.086 & 0.057 & 0.101 \\
\hline \multicolumn{10}{|c|}{ PANEL B: EMERGING MARKETS } \\
\hline \multirow[t]{2}{*}{ BRAZIL } & Variance Ratio & 1.359 & 1.055 & 0.814 & 0.788 & 0.868 & 0.871 & 0.705 & 0.399 \\
\hline & P-value & 0.916 & 0.648 & 0.128 & 0.251 & 0.424 & 0.505 & 0.418 & 0.200 \\
\hline \multirow[t]{2}{*}{ MEXICO } & Variance Ratio & 0.809 & 0.981 & 1.023 & 1.101 & 1.025 & 0.630 & 0.474 & 0.516 \\
\hline & P-value & 0.124 & 0.437 & 0.562 & 0.682 & 0.601 & 0.248 & 0.191 & 0.306 \\
\hline \multirow[t]{2}{*}{ TURKEY } & Variance Ratio & 0.847 & 0.995 & 0.666 & 0.449 & 0.374 & 0.249 & 0.209 & 0.173 \\
\hline & P-value & 0.172 & 0.429 & 0.012 & 0.003 & 0.006 & 0.003 & 0.005 & 0.007 \\
\hline \multirow[t]{2}{*}{ SOUTH AFRICA } & Variance Ratio & 1.218 & 1.062 & 1.015 & 0.984 & 0.951 & 0.936 & 0.828 & 0.559 \\
\hline & P-value & 0.769 & 0.664 & 0.572 & 0.532 & 0.547 & 0.596 & 0.571 & 0.422 \\
\hline \multirow[t]{2}{*}{ CHINA } & Variance Ratio & 0.847 & 0.951 & 0.873 & 0.890 & 1.117 & 1.427 & 1.555 & 1.280 \\
\hline & P-value & 0.234 & 0.326 & 0.239 & 0.384 & 0.683 & 0.827 & 0.852 & 0.789 \\
\hline \multirow[t]{2}{*}{ INDIA } & Variance Ratio & 0.748 & 0.954 & 0.748 & 0.659 & 0.689 & 0.699 & 0.725 & 0.490 \\
\hline & P-value & 0.067 & 0.308 & 0.098 & 0.125 & 0.266 & 0.388 & 0.495 & 0.353 \\
\hline
\end{tabular}

This table reports variance ratios and their respective p-values obtained through randomization of monthly real log-returns, as computed by the difference between monthly nominal returns and monthly US inflation rate, of $12 \mathrm{MSCl}$ equity indices for several holding periods. Panel A reports the results for developed market indices and Panel B reports the results for emerging market indices.

Lastly, Figure 6 and Table 6 show the results of the same analysis done with excess returns. When excess returns are used, variance ratios of USA decline a significant amount and approach to their initial levels. But it is still a contender for the most mean-averting developed market. Japan's mean aversion is further weakened and its variance ratios go below unity in holding periods between 5 and 8 years. It now seems like a market which is very close to random walk and whose variance ratios fluctuate around unity. UK has become much more mean-reverting and it has the lowest variance ratios among all developed markets when excess returns are used. This is reflected in its $p$-values which allow us to reject the null hypothesis of random walk in holding periods longer 5 years. 

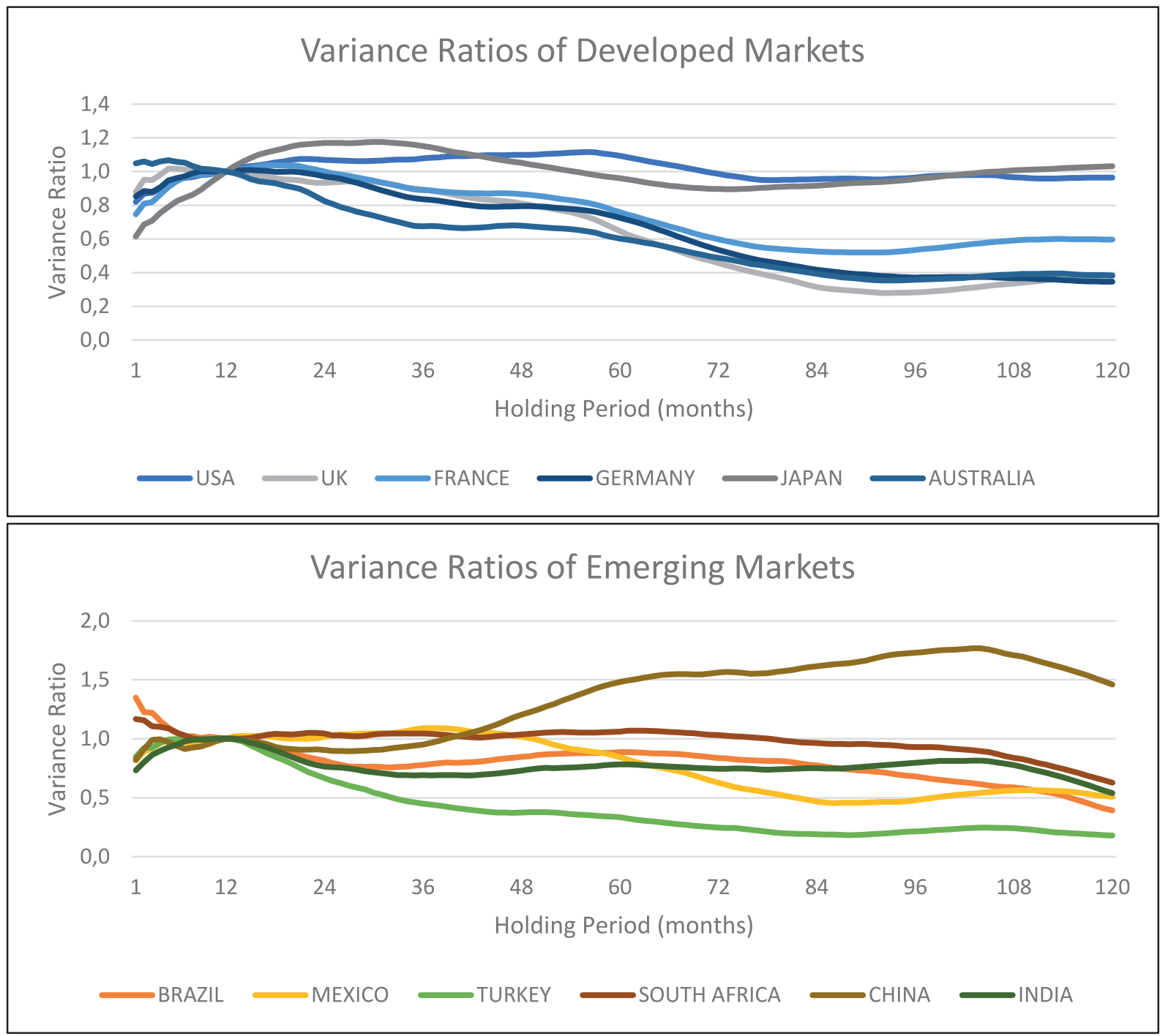

These figures display the variance ratios of the monthly excess log-returns, as computed by the difference between the monthly nominal return and monthly US risk-free rate of return, of $6 \mathrm{MSCl}$ developed market indices (USA, UK, France, Germany, Japan and Australia) and 6 MSCI emerging market indices (Brazil, Mexico, Turkey, South Africa, China and India) for holding periods from 1 month to 120 months.

Figure 6: Variance Ratios for Excess Returns of Country Indices.

A comparison among nominal, real and excess return results yields that developed markets are visibly more affected by the choice than the emerging markets. This can be seen in Table 7 which reports bigger absolute average percent changes in every return type for the developed markets.

A reasonable explanation for this might be the fact that we are using dollar denominated prices for all markets. Inflation and interest rates are usually much higher in emerging countries and when dollar denominated prices are used instead of prices denominated in local currencies, this might cause the effects of inflation and interest rates to be understated.
Another thing to note is the sign differences. Changing the return type has opposite effects for developed and emerging markets no matter which return types are used. For example, switching from nominal returns to real returns causes the variance ratios to increase for developed markets while it causes the variance ratios to decrease for emerging markets. Deciding on which return type to use for this type of analysis requires a more detailed investigation and it partly depends on investor profile and preference. It could be an excellent focal point for a future research paper on this topic. 
Table 6: Variance Ratios and Statistical Tests of Significance for Excess Returns of Country Indices.

\begin{tabular}{|c|c|c|c|c|c|c|c|c|c|}
\hline & & $\begin{array}{c}1 \\
\text { month }\end{array}$ & $\begin{array}{c}6 \\
\text { months }\end{array}$ & $\begin{array}{c}24 \\
\text { months }\end{array}$ & $\begin{array}{c}36 \\
\text { months }\end{array}$ & $\begin{array}{c}48 \\
\text { months }\end{array}$ & $\begin{array}{c}72 \\
\text { months }\end{array}$ & $\begin{array}{c}96 \\
\text { months }\end{array}$ & $\begin{array}{c}120 \\
\text { months }\end{array}$ \\
\hline \multicolumn{10}{|c|}{ PANEL A: DEVELOPED MARKETS } \\
\hline \multirow[t]{2}{*}{ USA } & Variance Ratio & 0.821 & 0.957 & 1.069 & 1.078 & 1.099 & 0.988 & 0.965 & 0.965 \\
\hline & P-value & 0.107 & 0.302 & 0.714 & 0.686 & 0.686 & 0.556 & 0.556 & 0.582 \\
\hline \multirow[t]{2}{*}{ UK } & Variance Ratio & 0.878 & 1.017 & 0.933 & 0.893 & 0.810 & 0.457 & 0.283 & 0.381 \\
\hline & P-value & 0.183 & 0.565 & 0.328 & 0.345 & 0.278 & 0.041 & 0.011 & 0.087 \\
\hline \multirow[t]{2}{*}{ FRANCE } & Variance Ratio & 0.746 & 0.942 & 1.000 & 0.891 & 0.866 & 0.599 & 0.534 & 0.597 \\
\hline & P-value & 0.016 & 0.193 & 0.540 & 0.348 & 0.368 & 0.133 & 0.151 & 0.243 \\
\hline \multirow[t]{2}{*}{ GERMANY } & Variance Ratio & 0.852 & 0.960 & 0.971 & 0.836 & 0.794 & 0.536 & 0.371 & 0.347 \\
\hline & P-value & 0.135 & 0.294 & 0.418 & 0.223 & 0.252 & 0.086 & 0.035 & 0.052 \\
\hline \multirow[t]{2}{*}{ JAPAN } & Variance Ratio & 0.615 & 0.824 & 1.169 & 1.151 & 1.052 & 0.896 & 0.955 & 1.031 \\
\hline & P-value & 0.002 & 0.005 & 0.922 & 0.792 & 0.621 & 0.456 & 0.552 & 0.620 \\
\hline \multirow[t]{2}{*}{ AUSTRALIA } & Variance Ratio & 1.048 & 1.057 & 0.825 & 0.674 & 0.679 & 0.488 & 0.358 & 0.385 \\
\hline & P-value & 0.574 & 0.709 & 0.087 & 0.052 & 0.109 & 0.047 & 0.029 & 0.078 \\
\hline \multicolumn{10}{|c|}{ PANEL B: EMERGING MARKETS } \\
\hline \multirow[t]{2}{*}{ BRAZIL } & Variance Ratio & 1.349 & 1.056 & 0.815 & 0.778 & 0.847 & 0.837 & 0.680 & 0.393 \\
\hline & P-value & 0.913 & 0.681 & 0.113 & 0.198 & 0.364 & 0.437 & 0.380 & 0.175 \\
\hline \multirow[t]{2}{*}{ MEXICO } & Variance Ratio & 0.815 & 0.992 & 1.014 & 1.088 & 1.016 & 0.629 & 0.479 & 0.508 \\
\hline & P-value & 0.144 & 0.462 & 0.579 & 0.661 & 0.574 & 0.257 & 0.205 & 0.313 \\
\hline \multirow[t]{2}{*}{ TURKEY } & Variance Ratio & 0.846 & 0.997 & 0.665 & 0.449 & 0.374 & 0.248 & 0.214 & 0.180 \\
\hline & P-value & 0.169 & 0.443 & 0.018 & 0.005 & 0.010 & 0.009 & 0.008 & 0.012 \\
\hline \multirow[t]{2}{*}{ SOUTH AFRICA } & Variance Ratio & 1.168 & 1.049 & 1.043 & 1.044 & 1.035 & 1.030 & 0.929 & 0.629 \\
\hline & P-value & 0.716 & 0.630 & 0.648 & 0.634 & 0.630 & 0.641 & 0.626 & 0.458 \\
\hline \multirow[t]{2}{*}{ CHINA } & Variance Ratio & 0.822 & 0.940 & 0.905 & 0.952 & 1.203 & 1.560 & 1.728 & 1.460 \\
\hline & P-value & 0.162 & 0.292 & 0.322 & 0.477 & 0.746 & 0.872 & 0.899 & 0.856 \\
\hline \multirow[t]{2}{*}{ INDIA } & Variance Ratio & 0.731 & 0.949 & 0.765 & 0.691 & 0.730 & 0.744 & 0.795 & 0.539 \\
\hline & P-value & 0.058 & 0.301 & 0.106 & 0.158 & 0.308 & 0.444 & 0.565 & 0.385 \\
\hline
\end{tabular}

This table reports variance ratios and their respective p-values obtained through randomization of monthly excess logreturns, as computed by the difference between monthly nominal returns and monthly US risk-free rate of return, of $12 \mathrm{MSCl}$ equity indices for several holding periods. Panel A reports the results for developed market indices and Panel B reports the results for emerging market indices. 
Table 7: Impact of Return Types on Variance Ratios.

\begin{tabular}{|c|c|c|c|}
\hline & REAL-NOMINAL & EXCESS-NOMINAL & EXCESS-REAL \\
\hline \multicolumn{4}{|c|}{ PANEL A: DEVELOPED MARKETS } \\
\hline USA & $14.63 \%$ & $0.69 \%$ & $-11.55 \%$ \\
\hline UK & $-4.43 \%$ & $-22.60 \%$ & $-19.86 \%$ \\
\hline FRANCE & $7.23 \%$ & $-8.42 \%$ & $-14.18 \%$ \\
\hline GERMANY & $5.47 \%$ & $-7.06 \%$ & $-11.68 \%$ \\
\hline JAPAN & $-11.59 \%$ & $-17.55 \%$ & $-7.26 \%$ \\
\hline AUSTRALIA & $13.78 \%$ & $6.93 \%$ & $-5.51 \%$ \\
\hline Average & $4.18 \%$ & $-8.00 \%$ & $-11.68 \%$ \\
\hline \multicolumn{4}{|c|}{ PANEL B: EMERGING MARKETS } \\
\hline BRAZIL & $-2.78 \%$ & $-4.96 \%$ & $-2.26 \%$ \\
\hline MEXICO & $-3.78 \%$ & $-4.02 \%$ & $-0.24 \%$ \\
\hline TURKEY & $-2.24 \%$ & $-1.72 \%$ & $0.55 \%$ \\
\hline SOUTH AFRICA & $-1.65 \%$ & $5.87 \%$ & $3.32 \%$ \\
\hline CHINA & $-1.65 \%$ & $5.87 \%$ & $3.32 \%$ \\
\hline INDIA & $-2.12 \%$ & $3.33 \%$ & $5.60 \%$ \\
\hline Average & $-2.37 \%$ & $0.73 \%$ & $1.71 \%$ \\
\hline WORLD AVERAGE & $0.90 \%$ & $-3.64 \%$ & $-4.98 \%$ \\
\hline
\end{tabular}

This table reports the average percent differences in variance ratios (1 month through 120 months) between different return types for all 12 countries in the data set.

\section{Conclusion}

This study was performed to shed some light on the times series behavior of international equity indices and to see if they show any signs of anomalies such as mean reversion or aversion. While all of the indices appear to have some degree of one or the other, most of them fail to show strong statistical significance to reject random walk hypothesis. This could be related to power of the test, which can be improved with more data; or simply the choice of data sample, as pointed out by Spierdijk et al. (2012).

For the data set subject to the analysis in this study, there was no evidence against the random walk for the international indices in the long-term, but there was evidence that EM and FM indices exhibit momentum in the short-term. Among the national indices, Turkey and Australia were proven to have mean reversion in the long-term while Japan was proven to have mean aversion in the short-term, although it is somewhat weakened when real or excess returns are used. Australia's mean reversion was also much stronger when nominal returns were used. Furthermore, there was evidence of mean aversion for France in the short-term and mean reversion for UK in the long-term, although the latter was only in excess returns.

The effect of dividends on the variance ratios was deemed negligible by the price-total return index comparison. On the other hand, size seems to be an important factor as there were significant differences in variance ratios between large, mid and small-cap equity indices. However, its impact varies quite a bit with respect to holding period and the market type. In the long-term, smaller size seems to push the variance ratios downwards for developed markets and upwards for emerging markets whereas in the short-term, it weakens the effect of momentum for developed markets and amplifies it for emerging markets.

Finally, changing the return type has a greater impact on developed markets than it has on emerging markets. This could be due to the high levels of inflation and interest rates in the emerging markets. Aside from the magnitude, the outcome of changing the return type is also different for developed and emerging markets. Going from one return type to the other, variance 
ratios always go opposite ways; upwards for developed markets and downwards for emerging markets or vice versa.

Our findings are consistent with the literature to a large extent. We observed momentum for short holding periods and mean reversion for long holding periods, just like Poterba and Summers (1989), Richards (1997) and many others. Unfortunately, the second part of that observation turned out to be difficult to prove. In that sense, our paper also resembles the likes of Chan (1988) and Kim, Nelson and Startz (1991) who same as us, could not reject the null hypothesis of random walk. Moreover, size-based comparisons of long-term variance ratios for developed markets support the findings of Fama and French (1988) while the same comparisons made for short holding periods contradict Lo and Mackinlay (1988) who claim the rejection of the random walk hypothesis gets stronger as size decreases. However, it should be noted that the data sets and in most cases methodologies of these papers are vastly different than ours. Therefore, these statements should be treated with caution and viewed only as a rough guide.

Overall, the results of this study were complicated, yet intriguing. It is clear that international equity returns display either mean aversion or reversion on a consistent basis across different holding periods. However, the statistical significance remains elusive, at least for the highly diversified international indices and country indices. It is also apparent that the different parts of the world behave differently, so do the equities with different sizes. A further study might explore individual style portfolios, industries or securities across countries, possibly denominated in the local currency, to make more accurate deductions. Such a detailed analysis would provide more information and possibly offer the elusive statistical significance for more conclusive results. 


\section{References}

Balvers, R., Wu, Y., \& Gilliland, E. (2000). Mean Reversion Across National Stock Markets and Parametric Contrarian Investment Strategies. The Journal of Finance, 55(2), 745-772. doi:10.1111/0022-1082.00225

Balvers, R. J., \& Wu, Y. (2006). Momentum and Mean Reversion Across National Equity Markets. Journal of Empirical Finance, 13(1), 24-48. doi:10.1016/j.jempfin.2005.05.001

Bhojraj, S., \& Swaminathan, B. (2006). Macromomentum: Evidence of Predictability in International Equity Markets. The Journal of Business, 79(1), 429-451. doi:10.1086/497416

Carhart, M. M. (1997). On Persistence in Mutual Fund Performance. The Journal of Finance, 52(1), 57-82. doi:10.1111/j.1540-6261.1997.tb03808.x

Chan, K. C. (1988). On the Contrarian Investment Strategy. The Journal of Business, 61(2), 147-61. doi:10.1086/296425

Chan, K., Hameed, A., \&Tong, W. (2000). Profitability of Momentum Strategies in the International Equity Markets. The Journal of Financial and Quantitative Analysis, 35(2), 153. doi:10.2307/2676188

Chaudhuri, K., \&Wu, Y. (2003). Mean Reversion in Stock Prices: Evidence From Emerging Markets. Managerial Finance, 29(10), 22-37. doi:10.1108/03074350310768490

Cochrane, J. H. (1988). How Big Is the Random Walk in GNP? Journal of Political Economy, 96(5), 893-920. doi:10.1086/261569

Conrad, J., \& Kaul, G. (1988). Time-Variation in Expected Returns.The JournalofBusiness,61(4),409.doi:10.1086/296441

DeBondt, W. F. M., \& Thaler, R. H. (1985). Does the Stock Market Overreact? The Journal of Finance, 40(3), 793-805. doi:10.1111/j.1540-6261.1985.tb05004.x

Fama, E. F. (1970). Efficient Capital Markets: A Review of Theory and Empirical Work. The Journal of Finance, 25(2), 383. doi:10.2307/2325486

Fama, E. F., \& French, K. R. (1986). Common Factors in the Serial Correlation of Stock Returns. UCLA: Finance. Retrieved from https://escholarship.org/uc/item/2jf8r7n7

Fama, E. F, \& French, K. R. (1988). Permanent and Temporary Components of Stock Prices. The Journal of Political Economy, 96(2), 246-273. doi:10.1086/261535

French, K. R., \& Roll, R. (1986). Stock Return Variances. Journal of Financial Economics, 17(1), 5-26. doi:10.1016/0304405x(86)90004-8

Gropp, J. (2004). Mean Reversion of Industry Stock Returns in the U.S., 1926-1998. Journal of Empirical Finance, 11(4), 537-551. doi:10.1016/j.jempfin.2004.04.002

Jegadeesh, N. (1990). Evidence of Predictable Behavior of Security Returns. The Journal of Finance, 45(3), 881-898. doi:10.1111/j.1540-6261.1990.tb05110.x
Jegadeesh, N. (1991). Seasonality in Stock Price Mean Reversion: Evidence from the U.S. and the U.K. The Journal of Finance, 46(4), 1427-44. doi:10.1111/j.1540-6261.1991. tb04624.x

Jegadeesh, N., \& Titman, S. (1993). Returns to Buying Winners and Selling Losers: Implications for Stock Market Efficiency. The Journal of Finance, 48(1), 65-91. doi:10.1111/j.1540-6261.1993.tb04702.x

Jegadeesh, N., \& Titman, S. (2001). Profitability of Momentum Strategies: An Evaluation of Alternative Explanations. The Journal of Finance, 56(2), 699-720. doi:10.1111/00221082.00342

Kendall, M. G., \& Stuart, A. (1976). The Advanced Theory of Statistics (3rd ed.) London, England: Griffin.

Kim, M., Nelson, C. R., \&Startz, R. (1991). Mean Reversion in Stock Prices?: A Reappraisal of the Empirical Evidence. The Review of Economic Studies, 58(3), 515-528. doi:10.2307/2298009

Lewellen, J. (2002). Momentum and Autocorrelation in Stock Returns. The Review of Financial Studies, 15(2), 533-563. doi:10.1093/rfs/15.2.533

Lo, A. W., \& MacKinlay, C. (1988). Stock Market Prices Do Not Follow Random Walks: Evidence from a Simple Specification Test. The Review of Financial Studies, 1(1), 41-66. doi:10.1093/rfs/1.1.41

Malkiel, B. G. (1973). A Random Walk Down Wall Street : The Time-Tested Strategy for Successful Investing (1st ed.). New York, NY: W.W. Norton.

McQueen, G. (1992). Long-Horizon Mean-Reverting Stock Prices Revisited. The Journal of Financial and Quantitative Analysis, 27(1), 1-18. doi:10.2307/2331295

Mukherji, S. (2011). Are Stock Returns Still Mean-Reverting?. Review of Financial Economics, 20(1), 22-27. doi:10.1016/j. rfe.2010.08.001

Patro, D. K., \& Wu, Y. (2004). Predictability of Short-Horizon Returns in International Equity Markets. Journal of Empirical Finance, 11(4), 553-584. doi:10.1016/j.jempfin.2004.02.003

Poterba, J., \& Summers, L. H. (1989). Mean Reversion in Stock Prices: Evidence and Implications. Journal of Financial Economics, 22(1), 27-59. doi:10.1016/0304-405X(88)90021-9

Richards, A. J. (1997). Winner-Loser Reversals in National Stock Market Indices: Can They Be Explained? The Journal of Finance, 52(5), 2129-44. doi:10.1111/j.1540-6261.1997. tb02755.x

Rouwenhorst, K. G. (1998). International Momentum Strategies. The Journal of Finance. 53(1), 267-284. doi:10.2139/ ssrn.4407

Shaik, M., \& Maheswaran, S. (2018). Expected lifetime range ratio to find mean reversion: Evidence from Indian stock market. Cogent Economics \& Finance, 6(1), 1475926. doi:10 $.1080 / 23322039.2018 .1475926$ 
Spierdijk, L., Bikker, J. A., \& van den Hoek, P. (2012). Mean reversion in international stock markets: An empirical analysis of the 20th century. Journal of International Money and Finance, 31(2), 228-249. doi:10.1016/j.jimonfin.2011.11.008
Vasicek, O. (1977). An Equilibrium Characterization of the Term Structure. Journal of Financial Economics, 5(2), 177-188. doi:10.1016/0304-405x(77)90016-2 